\title{
Grzegorz Wyczyński
}

Uniwersytet Wrocławski

e-mail: g.wyczynski@gmail.com

\section{Podmiotowość i transferowanie pojęć w badaniach nad grami wideo}

Słowa kluczowe: nowe media, metodologia, gry wideo, podmiotowość

Celem, jaki stawiam sobie w tekście niniejszym, jest przeanalizowanie pytania dotyczącego możliwości stosowania w obrębie badań nad grami wideo (game studies) pojęć z zakresu innych dyscyplin. Chcę przyjrzeć się temu zagadnieniu z metapoziomu, a więc z metodologicznego punktu widzenia.

W pierwszej chwili można odnieść wrażenie, że postawione tutaj pytanie jest już spóźnione, gdyż dotychczasowi badacze gier wideo dostarczyli zadowalających wniosków na temat ich relacji do innych mediów. Jesteśmy więc w stanie stwierdzić, na ile narzędzia analityczne z zakresu teorii literatury lub filmoznawstwa mogą być wykorzystywane w obrębie studiów nad cyberrozrywką. W pracy Języknowych mediów Lev Manovich konstatuje bardzo wyraźnie możliwość owocnego poznawczo stosowania już istniejących kategorii do analizy nowych mediów: „Korzystam w tej książce z narzędzi wypracowanych przez teorię filmu oraz inne nauki humanistyczne (historię sztuki, teorię literatury, medioznawstwo, socjologię) i informatykę"ı.

Opisując ewolucję komputerowych ekranów, powyższy autor wskazuje, iż kontynuują one elementy mediów starszych (druk, kino), poddając je jednak istotnym modyfikacjom i tym samym nadając im odmienny od dotychczasowego charakter: „Estetyczne

1 L. Manovich, Język nowych mediów, tłum. P. Cypriański, Warszawa 2006, s. 66. 
strategie kina stały się głównymi zasadami organizującymi oprogramowanie komputerowe. [...] To, co kiedyś było kinem, teraz jest interfejsem człowiek-komputer"².

W swoich rozważaniach chciałbym jednak wykonać krok wstecz i zmierzyć się z następującym pytaniem: W jaki sposób w punkcie wyjścia (a więc u samych źródeł danej dyscypliny) możliwe staje się racjonalne przejęcie już istniejących metod oraz schematów pojęciowych, aby następnie przy ich użyciu analizować nowe, wciąż jeszcze nie w pełni rozpoznane formy medialne? Wydaje się, iż pytanie takie, gdy już zostanie zadane, generuje zjawisko błędnego koła - wychodzimy bowiem od tego, co nieznane, aby w następnym kroku orzekać o jego relacji do tego, co już rozpoznane. Powstały problem można sformułować następująco: W jaki sposób na gruncie projektowania metodologii badań nad grami wideo ustalić warunki możliwości korzystania z narzędzi i ustaleń innych dyscyplin? Zanim przejdę do szczegółowego rozpatrzenia tego zagadnienia, chciałbym uprawomocnić jego postawienie kilkoma uwagami z zakresu teorii podmiotowości.

2 Ibidem, s. 167. Podobne obserwacje można w sposób uzasadniony sformułować również w odniesieniu do historycznie wcześniejszych mediów. I tak Andre Bazin, broniąc możliwości filmowych adaptacji tekstów literackich i teatralnych, stwierdził, że kino u swoich początków nie było sztuką „czystą". Nie pojawiło się ono od razu jako w pełni autonomicznie ukształtowana forma kulturowa: „Pierwsi filmowcy zaczerpnęli istotnie wiele z cyrku, music-hallu, widowisk jarmarcznych - chcieli oni bowiem zdobyć dla siebie ich publiczność; szczególnie burleska filmowa zaczerpnęła stąd i swą technikę, i swoich aktorów”. A. Bazin, Film i rzeczywistość, tłum. B. Michałek, Warszawa 1963, s. 84. Podobne uwagi odnajdujemy u Waltera Benjamina: „W historii wszystkich form sztuki występują okresy krytyczne, kiedy jakaś forma artystyczna zmierza do efektów, jakie swobodnie można by uzyskać tylko przy zmienionych warunkach technicznych, czyli w nowej formie". W. Benjamin, Dzieło sztuki w epoce możliwości jego technicznej reprodukcji, tłum. K. Krzemień, w: Estetyka i film, red. A. Helman, Warszawa 1972, s. 169. Sam Benjamin postrzegał kino jako spadkobiercę dadaistycznych strategii twórczych - ruchomy, wciąż zmieniający się obraz uderza widza, porywa go i wciąga w swój bieg, szokuje, nie pozostawiając czasu na kontemplację. Amerykański badacz mediów Allexander Galloway twierdzi tymczasem, że dopiero gry wideo w pełni wykorzystały i rozwinęły perspektywę subiektywną, którą wcześniej próbowano wprowadzać w filmie. Perspektywa ta nie polega na prostym i abstrakcyjnym utożsamieniu spojrzenia kamery z wewnątrzdiegetycznym spojrzeniem postaci (a poprzez to i spojrzeniem widza). Chodzi w niej o coś więcej - o głębokie zakotwiczenie kamery w ciele oraz doznaniach postaci. Gdy jest ona odurzona narkotykami bądź silnie czymś wzburzona, konstrukcja obrazu winna czytelnie oddawać te właśnie stany. Perspektywa subiektywna oferuje złudzenie pierwszoosobowego uczestnictwa w świecie przedstawionym, które nigdy nie jest jednak w pełni przekonujące, widzowie mogą bowiem patrzeć na świat oczyma postaci, zostaje im jednak odmówiony wpływ na jej działania: „O ile bierzemy pod uwagę identyfikację, ujęcie subiektywne przynosi filmowi klęskę, jednak jego klęska stanowi zwycięstwo gier (a to dlatego, że gry posiadają kontrolery i wymagają działań graczy). Gdy filmy posługują się ujęciem subiektywnym, aby reprezentować problem z identyfikacją, gdy posługują się ujęciem subiektywnym, by identyfikację tworzyć". A. Galloway, Gaming. Essays on Algorithmic Culture, University of Minnesota Press 2002, s. 69. 


\section{Społeczne konstruowanie podmiotowości}

W swoich rozważaniach nad zagadnieniem ideologii Louis Althusser stwierdził, że podmiotowość człowieka nie stanowi naturalnej danej, ale wytwór procesów formotwórczych spełnianych przez odpowiednie instytucje. To właśnie dzięki oddziaływaniu społeczeństwa uczymy się przeżywać nas samych oraz podejmowane przez nas działania w kategoriach podmiotowych. Z jednej strony czujemy się autorami naszych własnych działań, z drugiej zaś strony pozostajemy zależni od czegoś, co nas samych przerasta (Naród, Bóg, Partia) i czemu zawdzięczamy dar wolności:

W powszechnie akceptowalnym znaczeniu termin podmiot faktycznie oznacza: 1) wolną subiektywność [...]; 2) byt upodmiotowiony, podległy najwyższemu autorytetowi, a więc byt, któremu dano całą wolność, z wyjątkiem swobodnej akceptacji swej podległości. Ta ostatnia konotacja oddaje cały sens tej dwuznaczności, odzwierciedlającej skutek, który produkuje jednostka interpelowana, żeby stała się wolnym podmiotem po to, aby swobodnie podporządkowała się rozkazom Podmiotu, a więc po to, aby (swobodnie) zaakceptowała swoje upodmiotowienie, a więc po to, aby „całkiem sama dokonała" gestów i aktów swego upodmiotowienia³ .

Opisując proces ideologicznego przekształcania jednostki w podmiot, Althusser posługuje się metaforą policjanta zwracającego się do człowieka na ulicy. Ten ostatni, gdy słyszy głos przedstawiciela władzy, zatrzymuje się i odwraca, gdyż jest na to gotowy (przy narodzinach otrzymał imię, które zostało dla niego wybrane być może już wcześniej, gdy oczekujące na jego przyjście otoczenie już z wyprzedzeniem traktowało go w kategoriach podmiotowych). Althusserowską metaforę głosu poddała krytyce Judith Butler, twierdząc, że przypisuje ona aktom ideologicznej performatywności zbyt dużą (wręcz boską) władzę i skuteczność, a także łączy je z dającym się wyraźnie wskazać autorem. Proces upodmiotowienia jest tymczasem rozproszony i nie daje się sprowadzić do jakiegoś centrum. Pomimo powyżej zarysowanych uwag krytycznych Butler przejmuje od Althussera pogląd o społecznym konstruowaniu podmiotowości, przypisując w tym zakresie szczególną rolę językowi. To właśnie dzięki przyswojeniu sobie pewnego kodu lingwistycznego stajemy się zdolni do podejmowania działań przeżywanych jako coś wypływającego z naszego wnętrza. Jednak każdy język nosi na sobie piętno pierwotnej cenzury określającej, co można za jego pomocą wypowiedzieć. Podział na męski i żeński rodzaj gramatyczny; fakt, że pewne zawody mają w danym języku jedynie formę męską (przez co ich feminizacja wydaje się tak wielu osobom śmieszna lub wręcz sprzeczna z naturą); istnienie norm obyczajowych, w świetle których

3 L. Althusser, Ideologie i aparaty ideologiczne państwa, tłum. B. Ponikowski, J. Gajda, Warszawa 1983, s. $100-101$. 
mówienie określonych rzeczy nie przystoi kobietom lub mężczyznom - wszystkie te mechanizmy lingwistyczne służą zakorzenianiu w ludzkim ciele tożsamości płciowych. W ten sposób narzucają jednostkom szereg bezrefleksyjnie przyjmowanych ograniczeń, ale również aktywują samą możliwość działania:

Jeśli podmiot jest wytwarzany w mowie przez szereg wykluczeń, to owo założycielskie i formatywne ograniczenie tworzy scenę dla podmiotowej sprawczości. Sprawczość staje się możliwa jedynie pod warunkiem takiego wykluczenia. Nie jest to sprawczość suwerennego podmiotu, który zawsze jedynie sprawuje suwerenną władzę nad innymi. Chodzi o sprawczość podmiotu, który nie jest już suwerenny. Jej dyskursywne działanie jest $\mathrm{z}$ góry ograniczone, lecz także podatne na dalsze, nieoczekiwane ograniczenia ${ }^{4}$.

Nie miejsce tutaj na rozstrzyganie o trafności krytyki, jaką Butler wysunęła pod adresem Althussera. Chciałbym jednak podkreślić nacisk, jaki Butler kładzie w omawianym obecnie zakresie na rolę języka zorganizowanego w dyskurs. Sposób, w jaki mówimy oraz w jaki mówi się do nas, kształtuje naszą podmiotowość. Jeżeli chcemy być uznawani za w pełni kompetentnych uczestników życia społecznego, musimy operować językiem w narzucony nam sposób, a więc akceptować zawartą w nim pracę cenzurys. Zdaniem Butler podmiot istnieje tylko w i poprzez kulturę, zaś wszelkie próby opisania

4 J. Butler, Walczace stowa. Mowa nienawiści i polityka performatywu, tłum. A. Ostolski, Warszawa 2010, s. 161.

5 Oczywiście błędem byłoby sądzić, że sam tylko język jest narzędziem społecznej konstrukcji podmiotowości. Decydująca rola, jaką przypisuje mu w tym zakresie Butler, może łatwo sprawić, że stracimy z oczu inne formy socjalizacji. Równie ważne jest bowiem podpatrywanie zachowań innych ludzi, wpływ gier i zabaw, jakie dostępne są małym dzieciom, pozornie neutralna nauka właściwego zachowania w różnego rodzaju sytuacjach codziennych (spożywanie posiłków, korzystanie z komunikacji miejskiej, witanie gości etc.). W opisanych powyżej przypadkach spotykamy się bardzo często z milczącą pedagogiką: „Cała przewrotność rozumu pedagogicznego polega właśnie na wymuszaniu czegoś zasadniczego pod pozorem żądania drobiazgów”. P. Bourdieu, Szkic teorii praktyki poprzedzony trzema studiami na temat etnologii Kabylów, tłum. W. Kroker, Kęty 2007, s. 224. Nie oznacza to jednak, że cytowany Pierre Bourdieu negował rolę języka w procesie społecznego kształtowania podmiotowości. Wręcz przeciwnie, postrzegał on nabyte zasoby lingwistyczne jako istotny element kapitału kulturowego, który jednostka dziedziczy w ramach rodziny. Umiejętność wypowiadania się w określony sposób jest nierzadko koniecznym warunkiem, jaki trzeba spełnić, aby móc uczestniczyć w danym uniwersum społecznym. Na przykład profesor akademicki jest zobligowany do mówienia językiem akademii w istotny sposób różniącym się od języka używanego na budowie lub w codziennej konwersacji. Autor rozprawy doktorskiej, który operowałby w swoim wywodzie kolokwializmami oraz wulgaryzmami, musiałby się liczyć z odrzuceniem oraz oburzeniem swojego środowiska, nawet gdyby przeprowadzona przez niego argumentacja pozostawała bez zarzutu. Pomimo to wydaje się, że Butler przypisuje samemu językowi większą rolę w procesie konstruowania podmiotowości, niż robił to Bourdieu. 
naturalnej, pierwotnej ludzkiej egzystencji pozostają niemożliwe, gdyż historycznie ukształtowany język nie może uchwycić tego, co go poprzedza.

Uwagi powyższe pozwalają wskazać na fakt, że wraz z internalizacją określonych kodów kulturowych (w tym języka, również żargonu właściwego danej grupie społecznej) kształtuje się nasz stosunek do świata. To, jak widzimy rzeczywistość, mówimy o niej, oceniamy dokonujące się w jej obrębie wydarzenia, nie poddaje się eksplikacji czysto psychologicznej. Jesteśmy istotami społecznie zdefiniowanymi, co oznacza też, że nasza zdolność działania (oraz przeżywania podejmowanych działań w kategoriach podmiotowych) podlega społecznemu warunkowaniu. W naszych ciałach istnieją pewne dyspozycje i zdolności, jednak sposoby ich przejawiania się i rozumienia pozostają zawsze zdefiniowane przez dany kontekst socjohistoryczny i kulturowy.

Gdy w uniwersum akademickim pojawia się jakaś nowa dyscyplina, nie jest ona kształtowana przez sam swój przedmiot. Dzieje się tak między innymi dlatego, że tworzący ją ludzie sami pozostają uwarunkowani przez swoją dotychczasową praktykę badawczą oraz środowisko społeczne, w jakim ją realizowali. W związku z tym filmoznawca, literaturoznawca czy socjolog, gdy zdecydują się podjąć namysł nad jakimś nowym dla nich obszarem (np. grami wideo), mogą - w sposób spontaniczny oraz pozbawiony złej woli - projektować na niego dobrze już znane im kategorie. Kategorie, które sprawdziły się w dotychczasowej pracy akademickiej, co nie daje jednak gwarancji, że będą równie sprawnie funkcjonować w zderzeniu z innymi przedmiotami. Postępujący w ten sposób badacz bezwiednie dopuszcza się aktów przemocy symbolicznej, w konsekwencji których obiekt jego analiz zostanie zniekształcony, a czasami wręcz zupełnie unicestwiony. Na przykład akademicko wykształcona skłonność do kultury wysokiej może się przyczynić do zajęcia pogardliwego stosunku wobec gier wideo powszechnie łączonych z tym, co niskie, popularne i jedynie rozrywkowe. Taka elitarna postawa prowadzić będzie do analizy jedynie pozornej, polegającej na subsumowaniu danej formy kulturowej pod dostępne kategorie ${ }^{6}$. Wynikiem takich zabiegów może być konstatacja, że gry wideo stanowią formę uboższą pod względem fabularnym lub psychologicznym niż powieści, która nie przerodzi się jednak w pogłębioną refleksję nad rzeczywistymi różnicami między cyberrozrywkowymi a literackimi mechanizmami fabulacji. Istnieje jednak szansą, że respektowanie dostępnych środowiskowo kanonów sprawi, iż formułowane tezy łatwo uzyskają akademicką wiarygodność:

Zatem tendencja badaczy do koncentrowania się na problemach uznawanych za najważniejsze (na przykład dlatego, że zostały one ustalone jako najważniejsze przez twórców

6 „Gry elektroniczne kojarzy się jednoznacznie z kulturą popularną. W polskim odbiorze - najczęściej z kulturą «niską». To efekt wpływu szkoły frankfurckiej, w uproszczonej, zwulgaryzowanej wersji”. M. Filiciak, Wirtualny plac zabaw. Gry sieciowe i przemiany kultury wspótczesnej, Warszawa 2006, s. 15. 
cieszących się wysokim stopniem uznania) daje się tłumaczyć tym, że wkład do nauki bądź odkrycie naukowe z natury rzeczy przynosi znaczniejszy zysk symboliczny?

Gra wideo (tak samo jak każdy inny tekst kultury) stanowi tekst symboliczny, poddający się interpretacji wychodzącej zawsze z jakiegoś punktu widzenia. Innymi słowy, mamy tutaj do czynienia z obiektem znaczącym, który próbuje się opisać za pomocą określonych narzędzi pojęciowych. Te ostatnie nie są czymś doskonale przeźroczystym, ale niosą w sobie konkretny ładunek semantyczny. Powstaje więc pytanie, jak sprawić, aby te dwa obszary symboliczne zazębiły się ze sobą w sposób umożliwiający wytworzenie rzetelnej wiedzy. Jeżeli badacz zawsze jest uwarunkowany przez własne środowisko zawodowe oraz operuje językiem, jaki to środowisko na nim wymusza, jego stosunek do badanej rzeczywistości pozostaje symbolicznie predefiniowany. W związku z tym musi on włączyć w zakres swojej refleksji samego siebie oraz kategorie, którymi operuje. Jego stosunek do własnych narzędzi nie może pozostawać naiwny - fakt, że wcześniej sprawdziły się one w danym obszarze problemowym, nie sprawia automatycznie, że przeniesione w inny kontekst, dadzą równie zadowalające rezultaty:

Trzeba jednak pamiętać, że wiele z pojęć, którymi posługują się teoretycy, mimo tych samych nazw ma jednak różne zakresy semantyczne. Nawet jeśli ich rozumienie jest zbliżone, to nie ulega wątpliwości, że np. badanie narracji gier z perspektywy badań nad filmem doprowadzi do innych wniosków niż ich ogląd z perspektywy literackiej. Istotniejsze wydaje się więc na początku porównanie i przedyskutowanie sposobu definiowania pojęć $c^{8}$.

Istnieje coś takiego jak prawomocna mowa akademicka posiadająca swoje zakazy (np. wspomniane wcześniej unikanie kolokwializmów), nakazy (operowanie terminologią fachową) oraz martwe punkty (pewnymi zagadnieniami nie wypada się badawczo zajmować). Umiejętność sprawnego operowania nią stanowi warunek bycia uznanym za pełnoprawnego uczestnika życia naukowego:

Wyjście poza dziedzinę tego, o wypowiadalne, oznacza narażenie na szwank swojego statusu jako podmiotu. [...] „Niemożliwa mowa” byłaby właśnie bełkotem tego, co aspołeczne, tyradą tego, co „psychotyczne”. Sfery te wytwarzane są przez rządzące dziedziną wypowiadalności reguły i je nieustająco nawiedzająa

7 P. Bourdieu, Specyfika dziedziny naukowej i społeczne warunki rozwoju wiedzy, tłum. E. Neyman, w: Kryzys i schizma. Antyscjentystyczne tendencje w socjologii współczesnej, t. II, red. E. Mokrzycki, Warszawa 1984, s. 92.

8 J. Stasieńko, Alien vs. Predator-gry komputerowe a badania literackie, Wrocław 2005, s. 15.

9 J. Butler, Walczace slowa..., s. 154. 
Nawet jeżeli studia nad grami wideo nie stanowią już obszaru kontrowersyjnego czy uznawanego za niepoważny - można o nich swobodnie mówić oraz pisać - wciąż istotną kwestią jest prowadzenie pogłębionego namysłu metodologicznego nad metodami ich badania, bowiem podmiotowość badaczy oraz posiadane przez nich możliwości działania stanowią funkcję dostępnego im języka. Ten ostatni nie jest neutralnym przekaźnikiem informacji, ale wewnętrznie uwarunkowanym kodem powstałym i zdefiniowanym w obrębie historycznego pola akademickiego. W związku z tym refleksja nad pojęciami musi iść $\mathrm{w}$ parze $\mathrm{z}$ teorią praktyki badawczej rozumianej jako aktywność społecznie konstruowana. Pojęciami posługują się bowiem konkretni ludzie, ci zaś w momencie swoich narodzin nie stanowią gotowych leibnizjańskich całości, ale wytwory środowisk i instytucji, przez które przebiegają ścieżki ich życia. Instytucje te są zdolne do narzucania pewnych kategorii jako oczywistych i niepowątpiewalnych oraz promują ich prawowierne użycie określonymi korzyściami symbolicznymi.

Po szkicowym ugruntowaniu prowadzonych rozważań w ustaleniach z zakresu teorii podmiotowości w dalszej części wywodu przedstawię w czterech krokach model metodologiczny naświetlający warunki możliwości przenoszenia na grunt game studies pojęć z zakresu innych dyscyplin.

\section{Wariant historyczny}

Jeżeli w danej chwili istnieją dojrzałe już dziedziny wiedzy o różnych formach medialnych, może się wydawać, że zarysowany tutaj problem tak jakby sam się rozwiązuje. Jeżeli badacze komiksu doszli do pewnych konkluzji na temat jego odrębności od literatury, zaś filmoznawcom udało się określić, czym różni się kino od fotografii lub teatru, to stoimy na solidnych fundamentach pozwalających w sposób w pełni uzasadniony budować teorię. Podobną sytuację mielibyśmy w odniesieniu do gier wideo. Pogląd taki znajdujemy na przykład w rozważaniach Jona Doveya i Helen Kennedy, którzy w swojej przeglądowej książce z dziedziny game studies stwierdzają:

W miarę jak dziedzina się rozrastała, mogliśmy obserwować, jak zarówno tradycyjni, jak i radykalni uczeni adaptują istniejące podejścia, formułując jednocześnie nowe metodologie. My sami stopniowo hybrydyzujemy metodologie w sposób dobrze znany tym, którzy spędzili już sporo czasu, próbując zrozumieć działanie nowych mediów ${ }^{10}$.

Takie integracyjne podejście może czasami przyjmować formę swobodnych analogii publicystycznych (nie twierdzę, że z sytuacją taką spotykamy się u autorów powyżej

10 J. Dovey, H.W. Kenndy, Kultura gier komputerowych, tłum. T. Macios, A. Oksiuta, Kraków 2011, s. 111. 
wspomnianych). Mamy wówczas do czynienia z luźnymi konstatacjami stwierdzającymi naskórkowe podobieństwa pomiędzy na przykład kinem i grami wideo. Polski pisarz Wojciech Kuczok twierdzi, że w filmach akcji (za przykład mogą tutaj posłużyć choćby obrazy Johna Woo czy film John Rambo Sylvestra Stallone z 2008 r.) śmierć ulega banalizacji poprzez wyrugowanie jej traumatycznych aspektów fizjologicznych i psychologicznych. Wrogowie protagonisty nierzadko bardziej przypominają wirtualne konstrukty z gier wideo, które rozpływają się w powietrzu po ich eliminacji, niż ludzi z krwi i kości:

w „ramboidalnym” kinie akcji trup pada tak gęsto, że widz po prostu nie nadąża z rejestrowaniem kolejnych zgonów. [...] Śmierć to niewiarygodna, błaha, na niby - jak w grach wideo; trupem padają ożywione elementy scenograficzne, widzom nie jest dane pomyśleć o nich jak o ludziach ${ }^{11}$.

Takie swobodne i nierzadko efektowne analogie nie są oczywiście niczym złym i pozostają w pełni dopuszczalne na gruncie publicystyki. Jeżeli jednak chcemy dokonać rzetelnej i pogłębionej analizy podobieństw i różnic zachodzących pomiędzy filmowymi i cyberrozrywkowymi formami prezentacji przemocy, musimy zdecydowanie poza nie wykroczyć. Powierzchowne podobieństwa mogą nierzadko skrywać głębokie różnice i aby uchwycić te ostatnie, trzeba wprowadzić dalsze rozróżnienia pojęciowe i analityczne (np. na treść przekazu oraz jego formę medialną, na co tak mocno nastawał Marshall McLuhan).

Jeżeli jednak pominiemy przypadki publicystyczne i ograniczymy nasze analizy do dyskursu akademickiego, czy można zasadnie twierdzić, że dotychczasowe osiągnięcia na gruncie danej dyscypliny stają się mocnymi punktami odniesienia dla kolejnych pokoleń badaczy? Jeżeli badacz $A$ na przestrzeni czasu $t_{l}$ doszedł do pewnych wniosków, to badacz $B$ w późniejszym czasie $t_{2}$ może z nich swobodnie korzystać, o ile jest przeświadczony o ich prawdziwości, a więc adekwatności do przedmiotu własnych analiz. Stanowisko takie wydaje się początkowo akceptowalne w swojej zdroworozsądkowej oczywistości, ale nie pozostaje w pełni wolne od obarczenia pewną problematycznością. Wątpliwości rodzi pytanie o źródła, z jakich korzystał badacz $A$ we własnych analizach. Zawsze można próbować wskazywać na jego poprzedników i inspiracje zaczerpnięte $\mathrm{z}$ ich prac albo też na niewątpliwą trafność przeprowadzonych przez niego obserwacji i rozumowań. W pierwszym przypadku rodzi się znowu pytanie o punkt wyjścia tych poprzedników, w drugim zaś o kategorie, które - być może w sposób nieuświadomiony - warunkowały percepcję badacza $A$, a więc realnie wpływały na jego obserwacje oraz ich wyniki. Wciąż otwarte pozostaje pytanie, w jaki sposób pierwsi badacze gier wideo mogli racjonalnie przyjąc w swoich analizach narzędzia pojęciowe wykorzystywane

11 W. Kuczok, To piekielne kino, Warszawa 2006, s. 42. 
do poznawania innych mediów. W ten sposób wpadamy w pułapkę niekończącego się poszukiwania stabilnych fundamentów, od których możemy wychodzić.

Konkludując, należy podkreślić, że jeżeli z metodologicznego punktu widzenia pytamy o możliwość stosowania kategorii czerpanych z innych dyscyplin na gruncie analiz cyberrozrywki, wariant historyczny nie wydaje się dostarczać odpowiedzi zadowalającej, fundamentalny aspekt tej kwestii pozostaje bowiem wciąż nietknięty. Ustalenia wcześniejszych myślicieli są oczywiście pomocne, ale rodzą wątpliwość w związku z własną prawomocnością. Skąd bowiem pierwsi badacze gier wideo, gdy zapożyczali się u literaturoznawców lub filmoznawców (albo sami byli reprezentantami tych dyscyplin), mogli wiedzieć, na ile ich własny przedmiot na takie operacje pozwala? Gry były wówczas nowym przedmiotem naukowych analiz, a więc stanowiły coś jeszcze nierozpoznanego. Nawet jeżeli wraz z upływem czasu pierwsze, spontaniczne zapożyczenia okazały się trafne, wciąż nierozpoznane pozostają umożliwiające je warunki. Wariant historyczny może nam pokazać, że transfery pojęć pomiędzy dyscyplinami są możliwe, jednak nie wyjaśnia nam ich mechanizmów. Dostarcza on niewątpliwie wartościowego materiału faktograficznego, który domaga się dalszych analiz.

\section{Wariant krytyczny}

Uświadomienie sobie kłopotów z propozycją powyższą może dać asumpt do poszukiwania szerszej perspektywy analitycznej. Być może należy wykonać krok wstecz i spojrzeć na całą sprawę z poziomu transcendentalnego, a więc sformułować pytanie właśnie o warunki możliwości poznawania relacji intermedialnych przez ludzki rozum?

W swoich refleksjach filozoficznych Immanuel Kant zapytywał o warunki możliwości wiedzy metafizycznej. Punkt wyjścia dla tak zdefiniowanych rozważań stanowiła dla niego obserwacja, że w toku swojego dotychczasowego rozwoju intelektualnego ludzie snuli „różne fantazje na temat niezliczonej ilości przedmiotów, łatwo przeto może się zdarzyć, że dla każdej nowej rzeczy można będzie znaleźć jakąś dawną, która będzie do niej pod pewnym względem podobna"'12.

Dotychczasowi teoretycy bytu byli tak zajęci konstruowaniem kolejnych koncepcji oraz polemizowaniem ze sobą, iż nie zadali sobie trudu związanego z zadaniem pytania o warunki możliwości własnej dyscypliny. Tymczasem zdaniem Kanta dopiero taka refleksja fundamentalna będzie w stanie dowieść, że jakaś forma poznania ma charakter autentycznie naukowy.

Pytanie o metafizykę doprowadziło tego autora do szerszej problematyki i przedzierzgnęło się w wątpliwość bardziej ogólną, dotykającą możliwości i granic samego

12 I. Kant, Prolegomena do wszelkiej przyszłej metafizyki, która będzie mogła wystapić jako nauka, tłum. B. Bornstein, Warszawa 1999, s. 3. 
poznania rozumowego. Stwierdzając, iż „właściwe sądy metafizyczne są wszystkie syntetyczne"13, wskazał on na konieczność określenia, jak w ogóle możliwe jest poznanie syntetyczne $a$ priori, realizujące się także w innych dziedzinach wiedzy, a więc w czystej matematyce i czystym przyrodoznawstwie. Aby jednak refleksja transcendentalna mogła mieć rzeczywistą wartość, musi ona w pierwszej kolejności zerwać z już dostępną wiedzą: „Tak więc wszyscy metafizycy są w czynnościach swych uroczyście i zgodnie z prawem zawieszeni tak długo, dopóki nie dadzą zadowalającej odpowiedzi na pytanie: W jaki sposób są możliwe syntetyczne poznania a priori"' ${ }^{\prime 4}$. Rozum ludzki winien zagłębić się w siebie, aby na tej drodze badać własne prawa warunkujące jego poznawczy stosunek do rzeczywistości.

Samo przywołanie w omawianym tutaj kontekście kantowskiej krytyki metafizyki może rodzić pewne wątpliwości. Wydaje mi się więc, że poszukiwanie odpowiedzi na pytanie leżące u fundamentów tego tekstu musi dokonywać się na innej drodze niż krytyka czystego rozumu, należy bowiem pamiętać, że praca teoretyczna Kanta odnosiła się do tej formy poznania, którą nazwał on syntetyczną a priori. Jej konstytutywny element stanowi nieobecność doświadczenia zmysłowego - jeżeli występuje w niej jakaś forma naoczności, to nie może ona mieć charakteru empirycznego. Należy więc zastanowić się, czy studia nad cyberrozrywką mogą być utożsamione $\mathrm{z}$,poznaniem a priori, czyli poznaniem [płynącym] z czystego intelektu i czystego rozumu"15. Moim zdaniem nie mogą - game studies muszą podążać ścieżką empiryczną. Rację ma Mirosław Filiciak, gdy stwierdza, że „ze względu na dynamiczny charakter gier, samodzielna rozgrywka jest elementem koniecznym, ale niewystarczającym do przeprowadzenia możliwie najpełniejszej analizy"16.

Problematyczna wydaje się również teza Kanta, iż na czas przeprowadzania refleksji transcendentalnej konieczne jest zawieszenie całokształtu wiedzy, do której się ona odnosi i która ma zostać przez nią racjonalnie ugruntowana. Jeżeli badacz gier wideo dąży do określenia, na ile pewne kategorie z zakresu filmoznawstwa lub literaturoznawstwa dają się użyć w ramach jego własnych analiz, musi najpierw poznać te kategorie wraz z ich empirycznymi odniesieniami. Do osiągnięcia tego celu nie wystarcza jednak sama analiza rozumu i jego zdolności do apriorycznego poznania.

Analogiczne wątpliwości nasuwać się mogą wobec fenomenologicznej krytyki poznania Edmunda Husserla, której centralnym pytaniem były warunki możliwości wiedzy o obiektach ekstramentalnych. Chociaż Husserl odnosił się krytycznie do kantowskiego rozróżnienia na zjawisko i rzecz w sobie (dążąc do wyrugowania tej drugiej

\footnotetext{
13 Ibidem, s. 28.

14 Ibidem, s. 39.

15 Ibidem, s. 16.

16 M. Filiciak, Wirtualny plac zabaw..., s. 29-30.
} 
kategorii i postulował czystą analizę egologiczną ujmującą rzeczy jako fenomeny dane świadomości), również utrzymywał, że pytanie o warunki możliwości poznania musi zrzec się korzystania z dostępnej wiedzy o świecie. Jeżeli nie wiemy, w jaki sposób świadomość może dosięgać w sposób adekwatny obiektów leżących poza jej obrębem, nie możemy budować epistemologii na bazie historii, psychologii, biologii etc. Wejście na ścieżkę fenomenologicznej teorii poznania sprawia, że wszelka wiedza naukowa traci swoje ufundowanie:

Skoro niejasne jest dla mnie, jak poznanie może utrafić coś transcendentnego, coś, co nie jest samoobecnie dane, lecz domniemane w taki sposób, iż domniemanie wykracza tu poza siebie, to z pewnością w uzyskaniu jasności nie może mi tu pomóc żadne z transcendentnych poznań czy nauk. [...] chcę zobaczyć istotę możliwości tego utrafienia, chcę doprowadzić do jego oglądowej prezentacji1 ${ }^{17}$.

Aby odpowiedzieć na tak fundamentalne pytanie, należy wycofać myślenie ze świata empirycznego i oprzeć je na jedynie pewnym fundamencie, który wskazuje filozofia kartezjańska - świadomość musi skierować się ku sobie i własnym przeżyciom, co sprawia, że przedmiot poznania staje się immanentny samej kognicji. Następnie dzięki stosowaniu odpowiednich technik dokonujemy oczyszczenia uzyskanych wglądów i od konkretnych przeżyć psychicznych dochodzimy do powszechnie ważnych poznań istotowych - oglądamy „czerwień samą” lub „uczucie samo” (innymi słowy, od prostej immanencji efektywnej dochodzimy do immanencji czystej samoprezentacji). Tak osiągnięte konkluzje, ponieważ dotyczą tego, co ogólne i esencjalne, nie mają już odniesienia do bytu czasoprzestrzennego, gdzie mamy zawsze do czynienia z konkretnymi obiektami barwnymi, nie zaś samymi barwami.

Zarysowane powyżej stanowiska ze względu na swoje fundamentalne ambicje wydają się dla prowadzonych tutaj rozważań nazbyt abstrakcyjne. Nie chodzi mi bowiem o odpowiedź na pytanie, jak możliwe jest poznanie w ogóle, ale o rozwiązanie konkretnego problemu dotyczącego transferu pojęć między konkretnymi dziedzinami wiedzy. Nie szukam podstaw wiedzy o transcendensach czy też warunków możliwości metafizyki jako nauki. Można jednak potraktować powyższe projekty transcendentalne jako źródła inspiracji dla różnych dziedzin naukowej refleksji dążących do znalezienia dla siebie stabilnych fundamentów. Jednak inspiracje te nie mogą przesłaniać momentów problematycznych tkwiących w myśli zarówno Kanta, jak i Husserla. Na przykład wbrew drugiemu z nich należy stwierdzić, że fenomenologicznie uzyskane wglądy zawsze pozostają względne, gdyż dokonują się z perspektywy konkretnego miejscu oraz czasu. $Z$ naiwnego punktu widzenia może się wydawać, że istota na przykład barwy czerwonej jest zawsze i wszędzie taka sama, w związku z czym dla tak elementarnych kwestii

17 E. Husserl, Idea fenomenologii, thum. J. Sidorek, Warszawa 2008, s. 14. 
podejście fenomenologiczne zachowuje powszechną ważność. Głębsza refleksja nad tym zagadnieniem pozwala jednak uznać taki optymizm za przedwczesny - refleksje młodego Karola Marksa nad historycznością ludzkiego oglądu zmysłowego lub też koncepcje mediów jako przedłużenia człowieka autorstwa McLuhana pokazują, że to, jak widzimy i słyszymy, pozostaje wielostronnie uwarunkowane przez epokę, kulturę, technikę.

\section{Wariant definicji wstępnych}

Ėmile Durkheim w swoich rozważaniach metodologicznych ukuł pojęcie definicji wstępnych odnoszące się do twierdzeń, których zadaniem jest wyodrębnianie pewnych obszarów rzeczywistości jako przedmiotów naukowej analizy. Twierdzenia te nie stanowią więc punktów dojścia projektów badawczych, ale przeciwnie - ich punkt wyjścia. Konstrukcja definicji wstępnych dokonuje się na drodze ujmowania najbardziej powierzchownych cech rzeczy, najsilniej narzucających się swobodnemu oglądowi rzeczywistości: „Skoro definicja [...] tworzona jest na początku pracy naukowej, zadaniem jej nie może być wyrażenie istoty rzeczywistości; definicja ta powinna uczynić nas zdolnymi do jej późniejszego odkrycia"18. Jeżeli w toku dalszych badań okaże się, że ich odnośne przedmioty nie dają się pogodzić z treścią wyjściowych definicji, to właśnie te drugie będą musiały zostać zmienione.

U samego Durkheima takie założenie metodologiczne zostało zastosowane na przykład w badaniach z zakresu socjologii religii. W ich punkcie wyjścia zawieszone zostały dostępne koncepcje badanych zjawisk, gdyż mogły one posiadać charakter wykluczający. I tak na przykład pogląd, w myśl którego we wszystkich religiach występuje relacja ludzi do transcendencji, nie wytrzymuje weryfikacji ze strony dostępnych świadectw empirycznych - są bowiem nieteistyczne systemy wiary. Należy więc najpierw badać fakty religijne, traktując je jako elementy ekstramentalnej rzeczywistości, do której badacz ma dostęp jedynie empiryczny, aby dopiero w konsekwencji ich analizy dojść do pewnych uogólnień teoretycznych:

Z powiedzianego powyżej wypływa, że przystępując do tego określenia, powinniśmy pozostawić na stronie wszystkie mniej lub więcej ustalone mniemania, jakie każdy z nas może mieć o religii, idzie tu bowiem o same fakty religijne, nie zaś o to, jak my je sobie wyobrażamy. Trzeba wyjść poza siebie i wejść w styczność z samymi rzeczami ${ }^{19}$.

Wydaje mi się, że przywołane powyżej stanowisko przybliża nas do rozwiązania rozważanego problemu, pozwala ono bowiem na nazywanie rzeczy i tym sposobem wy-

18 È. Durkheim, Zasady metody socjologicznej, tłum. J. Szacki, Warszawa 2007, s. 72.

19 È. Durkheim, Próba określenia zjawisk religijnych, tłum. S. Brzozowski, Warszawa 1903, s. 6. 
różnianie jako przedmiotów badań. Gdy w punkcie wyjścia przyjmiemy jakąś definicję gier wideo, umożliwi nam ona - poprzez porównywanie jej z definicjami innych mediów oraz ich elementów - na wysunięcie wstępnych tez metodologicznych mówiących o relacjach pomiędzy game studies a innymi dyscyplinami. Jeżeli jednak w toku dalszych analiz okaże się, że wstępna definicja nie koresponduje w sposób zadowalający ze swoim przedmiotem, jesteśmy w stanie albo ją porzucić i rozpocząć pracę od nowa, albo też podjąć próbę jej modyfikacji.

U samego Durkheima koncepcja definicji wstępnych miała za zadanie tak ugruntować poznanie socjologiczne, aby wychodziło ono nie od subiektywnych wyobrażeń na temat rzeczywistości społecznej, ale od samej tej rzeczywistości dostępnej badaczowi na drodze obserwacji: „Trzeba więc, by socjolog zarówno w momencie określania przedmiotu swych badań, jak i w trakcie przeprowadzania dowodów zakazał sobie stanowczo korzystania z pojęć ukształtowanych poza nauką i dla zgoła nienaukowych celów”20.

Mówiąc o nienaukowych pojęciach, chodziło mu przede wszystkim o te funkcjonujące w ramach języka potocznego - ludzie bowiem tworzyli sobie pewne wyobrażenia na temat otaczającego ich świata na długo przed tym, gdy ten ostatni stał się obiektem naukowych analiz ${ }^{21}$. Pewne wątpliwości może więc budzić takie odczytanie tez metodologicznych Durkheima, które eksponuje już istniejące pojęcia (nawet jeżeli pochodzą one ze słowników naukowych) jako punkty wyjścia w zakresie konstruowania wstępnych definicji. Uważam jednak, że nie jest to wątpliwość unieważniająca wszystko, co zostało powyżej powiedziane. Jeżeli dany badacz w konsekwencji wstępnego oglądu gier wideo dojdzie do wniosku, że są one medium z istoty swojej narracyjnym, może sięgnąć ku kategoriom dostarczanym na przykład przez badania literackie, aby przy ich użyciu sformułować wyjściową definicję własnego przedmiotu. Gdy zaś w toku dalszych badań okaże się, że istnieją poważne powody dla wytyczenia różnicy pomiędzy literackimi a cyberrozrywkowymi formami narracji, może on wykonać krok wstecz i redefiniować wyjściowe kategorie, aby tym sposobem nadać ich relacji do rzeczywistości większy stopień adekwatności. Gdy zaś w toku swoich poszukiwań napotka gry abstrakcyjne (jak np. Tetris) lub też nienarracyjne gry sportowe, proces modyfikowania może pójść jeszcze dalej - koncepcja gry jako formy narracyjnej ulegnie przekształceniu w szersze ujęcie, w ramach którego narracja zostanie uznana za czynnik definiujący tylko niektóre obszary cyberrozrywki.

Podajmy konkretne przykłady: analizując badania autorów wpisujących się w ramy konsekwentnej narratologii, Dovey i Kennedy wskazali, iż przyjęta przez nich a priori definicja gier cyfrowych jako form fabularnych doprowadziła w ostateczności do konkluzji, iż „próba zastosowania teorii literatury prowadzi [...] w ślepy zaułek”22. Duża

20 È. Durkheim, Zasady metody socjologicznej, s. 61.

21 Ibidem, s. 42.

22 J. Dovey, H.W. Kenndy, Kultura gier komputerowych, s. 114. 
część gier wideo okazuje się pod względem fabularnym niezwykle uboga w porównaniu z tekstami literackimi. Idąc dalej - można nawet wykazać, iż w przypadku niektórych gatunków cyberrozrywki (jak np. MMORPG) narracja niejako zamiera, gdyż dostępne za pośrednictwem internetu wirtualne światy mogą być jednocześnie eksplorowane przez potencjalnie nieskończoną liczbę użytkowników. Wówczas każdy z nich, podejmując za pośrednictwem swojego awatara różne działania w obrębie fikcjonalnego świata przedstawionego, buduje własną całostkę narracyjną. Mnogość tych całostek nigdy nie zbiega się - i zbiec się nie może - w jakąś całościową i zamkniętą opowieść. Zdaniem Jong-Ho Piha gry tego typu stanowią pierwszą formę artystyczną, która ,jako protagonistów przedstawiałaby niezliczone podmioty"23, i w związku z tym radykalnie zmieniają charakter narracji oraz sposób jej doświadczania. Także przywoływany już Manowich stwierdza, że w przestrzeni badań nad nowymi mediami pewne dostępne definicje narracyjności muszą być zmieniane, jeżeli mają być stosowane w sposób adekwatny. Pogląd, w myśl którego każda struktura narracyjna dzieli się na elementy fabuły i opisu, należy przeformułować w odniesieniu do gier wideo. W przypadku tych ostatnich bardziej uzasadnione jest mówienie o narracyjności i eksplorowaniu, które nie wykluczają się wzajemnie (badania przedmiotu przerywa bieg historii), ale przeciwnie - uzupełniają:

Gracz nie jest biernym uczestnikiem narracji, wprost przeciwnie, musi wykonywać jakieś czynności, żeby napędzać akcję: rozmawiać z napotkanymi postaciami, podnosić rzeczy z ziemi, walczyć z przeciwnikami. [...] Penetrowanie przestrzeni świata gry, badanie jego szczegółów, oglądanie jego obrazów jest równie istotne dla sukcesu gier takich, jak Myst i następujące po niej, jak podążanie przez narrację. [...] Zatem działania będące częścią narracji i eksplorowanie świata gry są blisko ze sobą związane ${ }^{24}$.

Analizy metodologiczne Durkheima wydają się dawać dobry punkt zaczepienia dla analizowanego w tym tekście problemu. Chociaż z jednej strony zalecają uzasadniony sceptycyzm względem kategorii, które badacz zastaje w stanie gotowym u początków swej pracy, z drugiej strony dopuszczają ich ostrożne i krytyczne stosowanie. Możemy w odniesieniu do gier cyfrowych mówić o fabule, narracji, zbliżeniach, perspektywie subiektywnej czy świecie przedstawionym, o ile będziemy te kategorie traktować jako narzędzia służące wstępnemu rozpoznaniu terenu. Nie da się bowiem wskazywać przedmiotów badawczych bez pośrednictwa języka. Stojąc wobec bogactwa materiału badawczego, musimy być w stanie wydobywać z niego przedmioty naszych analiz oraz je rozróżniać. Jeżeli twierdzimy, że dana gra posiada świat przedstawiony lub linię fabularną, konkretyzujemy sposób oraz kierunek ich badania, jednak to nie rozwią-

23 J.-H. Pih, Zagadnienia narratologiczne w grach komputerowych, tłum. K. Krzemieniowa, w: Pogranicza audiowizualności, red. A. Gwóźdź, Kraków 2010, s. 462.

24 L. Manovich, Język nowych mediów, s. 368-369. 
zuje jeszcze całej sprawy, wciąż bowiem otwarte pozostają pytania o specyfikę fabuł cyberrozrywkowych, a więc konieczne jest dalsze zagłębianie się w dostępny materiał empiryczny, aby nasączać wybrane kategorie konkretną treścią. Konieczne staje się ciągłe kursowanie pomiędzy abstrakcją i konkretem, budowaną teorią a rzeczywistością, którą próbuje ona opisywać i wyjaśniać.

\section{Wariant dialektyczny}

We Wprowadzeniu do krytyki ekonomii politycznej Marks zaproponował dialektyczny model definiowania pojęć oparty na ciągłym kursowaniu pomiędzy dwoma sprzecznymi momentami - tym, co konkretne, oraz tym, co abstrakcyjne. Wydaje się, że w badaniach ekonomicznych należy wychodzić od tego, „, co realne i konkretne”25, czyli od kategorii opisujących fundamenty społecznego procesu produkcji, takich jak na przykład „ludność". Ale w toku dalszego zagłębiania się za ich pomocą w empiryczną rzeczywistość coraz bardziej widoczna staje się jej wewnętrzna złożoność - podział całości na klasy społeczne, grupy zawodowe etc. W ten sposób od kategorii początkowych umysł dociera do szeregu coraz prostszych pojęć, takich jak ,praca” lub „,wartość”. Wówczas aby scalić ze sobą dwa wymienione wcześniej momenty - konkret i abstrakcję - poznający podmiot musi udać się w drogę powrotną, wiodącą ku punktowi wyjścia, który w toku uprzednio poczynionych doświadczeń ulega modyfikacji. Proste pojęcia wyjściowe zostają nasączone konkretną treścią, stając się tym samym mentalnym obrazem „bogatego całokształtu wielu określeń i stosunków”26. Mamy tu więc do czynienia z ruchem o dwustronnym ukierunkowaniu: „W wyniku pierwszej metody pełne wyobrażenie wysublimowało się w abstrakcyjne określenie; druga metoda powoduje, że abstrakcyjne określenia wiodą do odtworzenia tego, co konkretne, w drodze myślenia"'27.

Raz zdefiniowane kategorie nie stają się jednak absolutnymi punktami odniesienia w obrębie poznania naukowego, pojęcia są bowiem tak samo historyczne jak świat, do którego się odnoszą. Aby więc nie czynić ich bezdomnymi, musimy wyrzec się absolutystycznych oczekiwań i porzucić nadzieję, że świat stanie w miejscu gwoli dopasowania się do naszych precyzyjnych schematów pojęciowych. Sam Marks był w pełni świadomy faktu nie tylko historycznego, ale także synchronicznego zróżnicowania rzeczywistości społecznej (o czym świadczą choćby jego późne rozważania o wspólnocie rolnej w Rosji i jej stosunku do form gospodarowania ziemią w innych społeczeństwach kapitalistycznym). Dlatego też wskazywał na konieczność ciągłego odnoszenia raz wypracowanych kategorii do dynamicznej rzeczywistości - bez takiego ruchu weryfikacji posługiwanie

25 K. Marks, Wprowadzenie do krytyki ekonomii politycznej, w: MED, t. XIII, Warszawa 1966, s. 721.

26 Ibidem, s. 722.

27 Ibidem. 
się nimi traci swój sens: „Abstrakcje te w oderwaniu od rzeczywistej historii nie mają same przez się żadnej zgoła wartości’’28.

Zaproponowane powyżej ujęcie wydaje się szczególnie wartościowe w zakresie badania gier wideo, i to przynajmniej z dwóch powodów. Po pierwsze, dobrze uzupełnia wcześniejsze stanowisko Durkheima - jeżeli definicje wstępne pozwalają nam wyłonić pojęcia i kategorie opisujące gry cyfrowe i ich relacje do innych mediów, to praca dialektyczna sprawia, iż uzyskane schematy pojęciowe nie ulegną petryfikacji. Ciągłe kursowanie pomiędzy abstrakcją i konkretem pozwala ustrzec myślenie przed wpadnięciem w pułapkę spekulacji sprawiającej, że abstrakcje stają się czymś istotniejszym i bardziej wiążącym niż sama rzeczywistość: „Przejście od abstrakcji do jej przeciwieństwa jest nawet niemożliwe, jeśli nie zrezygnuje się z abstrakcji”29. Dialektyka pojęć pozwala na odrzucenie złej abstrakcji (spekulacji) przy zachowaniu pojęć ogólnych niezbędnych w ramach teoretycznej artykulacji rzeczywistości.

Dochodzimy więc do drugiego istotnego punktu - gry wideo stanowią medium rozwojowe, w ramach którego ujawniają się wciąż nowe formy, gatunki, sposoby dystrybucji czy platformy technologiczne. Ich badanie wymaga więc wyostrzonej czujności. Tezę taką stawia na przykład Filiciak: „należy już dziś skatalogować procesy związane z nowymi mediami i stworzyć narzędzia, które pozwolą uchwycić specyfikę kultury elektronicznej, zwłaszcza że ze względu na swój dynamiczny charakter popularne dziś przejawy kultury cyfrowej mogą z czasem po prostu zanikać" ${ }^{30}$. Nie tylko szybki rozwój samego medium, ale również ewolucja jego bazy technologicznej (kultura apgrejdu ${ }^{31}$ ) wymuszają ciągłą gotowość do sprawdzania i modyfikowania pojęć, którymi już operujemy w badaniach nad nowymi mediami.

Zilustrujmy pracę obecnego wariantu na konkretnym przykładzie: Jesper Jull w jednej ze swoich książek zastanawia się nad możliwością gry, w której bohater sterowany przez gracza od samego początku dąży do samozagłady. W sferze literatury lub filmu łatwo wskazać przykłady dzieł przedstawiających straceńców lub samobójców. W ramach tych mediów mamy jednak do czynienia z formami, gdzie (pomimo feno-

28 K. Marks, F. Engels, Ideologia niemiecka, w: MED, t. III, Warszawa 1975, s. 29.

29 K. Marks, F. Engels, Święta rodzina, czyli krytyka krytycznej krytyki, w: MED, t. II, Warszawa 1961, s. 70.

30 M. Filiciak, Wirtualny plac zabaw..., s. 14. Na palącą konieczność tworzenia historii cyfrowej wskazuje również Manovich. Dynamiczny rozwój technologii informatycznych, bez uwzględniania których nie da się w pełni pojąć specyfiki nowych mediów, sprawia, że to, co dzisiaj jawi się jako nowe, już jutro ulegnie oswojeniu lub dezaktualizacji. Dlatego też „można by zapytać, dlaczego nawet nie próbowano ustalić genezy języka mediów komputerowych wówczas, kiedy się tworzył, to znaczy w chwili, kiedy poszczególne elementy form kulturowych, które kształtowały ów język, były widoczne i łatwe do rozpoznania, bo nie połączyły się jeszcze w jednorodną całość”. L. Manovich, Język nowych mediów, s. 63.

31 J. Dovey, H.W. Kenndy, Kultura gier komputerowych, s. 66. 
menu projekcji-identyfikacji sprawiającego, że przedstawione postacie oraz ich los nie pozostają nam obojętne) odbiorca nie jest aktywnym uczestnikiem zdarzeń, ale jedynie ich obserwatorem. Istnieją jednak gry - na przykład utrzymane w konwencji westernu Red Dead Redemption - które zakończyć się mogą jedynie śmiercią grywalnej postaci. Ich odbiorcy nie zostają jednak od razu poinformowani o tym, jak skończą się ich wirtualne przygody. W tym sensie omawiany tytuł różni się na przykład od filmu irańskiego reżysera Abbasa Kiarostami Smak wiśni opowiadającego o mężczyźnie poszukującym kogoś, kto pomoże mu w popełnieniu samobójstwa. W Red Dead Redemption zagłada nie jest celem rozgrywki, chociaż koniec końców nawet najbardziej zaangażowani i sprawni gracze nie będą w stanie jej uniknąć:

gracze w Red Dead Redemption nie zostają konkretnie poinformowani, że kiedy ukończą grę, ich postać umrze, a oni sami pozostaną bezsilnymi świadkami jej zabójstwa. Ich reakcje okazują się podzielone - niektórzy odczuwają oburzenie, że nie są w stanie ocalić głównego bohatera, inni akceptują to rozwiązanie, gdyż dobrze wpisuje się w fabułę gry ${ }^{32}$.

Powyższy przykład pozwala uwidocznić, jak w odniesieniu do gier wideo pracuje metoda dialektycznego formułowania pojęć. Jeżeli udało nam się ustalić i ugruntować pogląd, że gry - podobnie jak filmy i powieści - opowiadają jakieś historie czy posiadają bohaterów, natykając się na tytuły typu Red Dead Redemption, uzyskujemy możliwość empirycznego pogłębienia powyższych kategorii. Tak samo jak w literaturze czy kinie, w obrębie gier wideo funkcjonują różne formy narracji czy gatunki fabuł. Uzasadnione jest mówienie o westernie filmowym i cyberrozrywkowym, jednak bardziej dokładna analiza pokazuje, że w tych dwóch sferach pewne mechanizmy narracyjne funkcjonują zgoła odmiennie i wywołują różne reakcje (emocjonalne, intelektualne) u odbiorców.

Gry wideo jako medium aktywnie angażujące odbiorców w przebieg przedstawianych wydarzeń kreują u nich szereg właściwych sobie oczekiwań i przyzwyczajeń. Gracze chcą mieć większy wpływ na przebieg akcji i w sposób zasadny oczekują, że umiejętności, które zdobyli w toku dotychczasowych rozgrywek, zaowocują w przyszłości coraz lepszymi wynikami oraz częstszymi zwycięstwami:

Wysiłek gracza to inny sposób stwierdzenia, że gry są wyzwaniem albo że gry zawierają konflikt, lub że gry są ,interaktywne”. Elementem większości gier (z wyjątkiem gier losowych) jest założenie, że działania graczy mogą wywierać wpływ na stan gry lub wynik gry ${ }^{33}$.

32 J. Juul, Sztuka przegrywania. Esej o bólu, jaki wywołuja gry wideo, tłum. P. Schreiberm, M. Tabaczyński, Kraków-Bydgoszcz 2016, s. 87.

33 J. Juul, Gra, gracz, świat: w poszukiwaniu sedna „growości”, tłum. M. Filiciak, w: Światy z pikseli. Antologia studiów nad grami komputerowymi, red. M. Filiciak, Warszawa 2010, s. 49-50. 
Dlatego też nieuchronność pewnych wydarzeń ma w nich inny charakter niż w zamkniętych narracjach filmowych lub literackich. Na przykład w grze Mafia III gracze dowiadują się z przerywnika filmowego, że jedna z towarzyszących głównemu bohaterowi postaci zginie w kolejnej misji. Takie rozwiązanie narusza iluzję, że to, co dzieje się w wirtualnym świecie, zależne jest od decyzji i działań odbiorców. Gry nigdy nie są w pełni otwarte i interaktywne, a swoboda ruchów, jaką w nich dysponujemy, pozostaje ograniczona przez uprzednio powzięte decyzje programistów i producentów.

Przykład gry Mafia III każe po raz kolejny zastanowić się nad specyfiką cyberrozrywkowych fabuł oraz narracji. Śmierć towarzysza w gangsterskiej grze nie jest bowiem tym samym co analogiczna sytuacja w gangsterskim filmie. W tym drugim przypadku nie oczekujemy aktywnego wpływu na przebieg wydarzeń. Głębsze zastanowienie się nad tym zagadnieniem (dokonujące się w trybie kursowania pomiędzy abstrakcją i konkretem) może skłonić nas nawet do mocnej zmiany kategorii, z których dotychczas korzystaliśmy. Espen Aarseth, analizując niejednolite wewnętrznie zjawisko cybertekstu, stwierdził, że w przypadku powieści hipertekstowych nie mamy już do czynienia z narracją, ale z czymś od niej odmiennym, co w związku z tym domaga się innego nazwania. Wystąpił on więc z kategorią ergodyczności (która jego zdaniem znajduje także zastosowanie do opisu gier wideo): „Słowem, które proponuję w tym przypadku, jest ergodyczność, co ma sugerować sytuację, w której obrębie łańcuch wydarzeń (ścieżka, sekwencja działań i tak dalej) został stworzony za sprawą nietrywialnego wysiłku co najmniej jednej osoby lub mechanizmu"34.

Gry wideo od początków swojego istnienia zapożyczały się u starszych od siebie form kultury. Czerpały z kina, literatury, komiksu, i to na różnych poziomach, a więc zarówno w sferze form, jak i treści. Dziś ta relacja wydaje się ulegać odwróceniu posiadające dłuższą historię kino zaczyna czerpać z gier, aby wpisać się w przestrzeń gustów i oczekiwań młodych pokoleń widzów, których preferencje i nawyki percepcyjne ukształtowały się na fundamencie cyberrozrywki. Ta ostatnia wciąż jednak sięga do konwencji kinowych lub telewizyjnych, wpisując je we własne ramy i nadając im nową jakość (można tutaj wspomnieć ciepło przyjęty tytuł The Walking Dead z ubiegłego roku - oparty na komiksie pod tym samym tytułem, wydaje się rozmywać granicę pomiędzy telewizyjnym serialem a grą wideo). Sytuacja taka sprawia, że raz wypracowane kategorie mogą bardzo szybko zatracić swoją aktualność oraz adekwatność albo przynajmniej zachowywać ją jedynie lokalnie (a więc tylko wobec konkretnych gatunków). Tak więc postulat ciągłego zanurzania kategorii teoretycznych w zmieniającym się kontekście empirycznym wydaje się w omawianym zakresie bardzo wartościowy. Pozwala to na nieprzerwane ponawianie fundamentalnego pytania o relację pomiędzy badaniami gier a innymi dyscyplinami i w związku z tym na wypracowywanie nowych, coraz bardziej

34 E. Aarseth, Cybertekst. Spojrzenia na literaturę ergodyczna, tłum. zbiorowe, Kraków-Bydgoszcz 2014, s. 103. 
efektywnych i poznawczo uzasadnionych sposobów przemieszczania pojęć pomiędzy tymi dziedzinami. Granice pomiędzy mediami nie są ostre i raz na zawsze ustalone, co wymusza przyjęcie interdyscyplinarnej i refleksyjnej postawy badawczej świadomej faktu, że punkt widzenia podmiotu wyznacza jego stosunek do analizowanego przedmiotu. Rodzi to

postulat wyjścia „zza biurka”, ewentualnie „sprzed ekranu”, a więc rozszerzenie perspektywy dominującej w polskim, silnie związanym $z$ badaniami filmu medioznawstwie, o elementy socjologii i etnografii, mające pomóc $\mathrm{w}$ walce z Beckowskimi „pojęciami zombie” - konstruktami teoretycznymi, które funkcjonują na kartkach tekstów badaczy, ale dla których coraz trudniej znaleźć referencje poza nimi ${ }^{35}$.

\section{Konkluzja}

Scharakteryzowane powyżej warianty metodologiczne wcale nie muszą się wykluczać przyjęcie jednego z nich nie uniemożliwia odwoływania się do pozostałych. Przeciwnie, zarysowują się pomiędzy nimi wyraźne związki chronologiczne i logiczne. Wariant krytyczny inspiruje pogłębiony namysł nad samymi warunkami możliwości poznania. Fundamentalne projekty Kanta i Husserla, stworzone do celów innych niż postawione w niniejszym tekście, mogą rodzić u badaczy gier pewne intuicje oraz pytania metodologiczne, nie dostarczają jednak na nie zadowalających odpowiedzi. W kolejnym kroku należy więc sięgnąc do historii i przyglądać się sposobom dotychczasowego korzystania z kategorii teoretycznoliterackich lub filmoznawczych do opisu gier wideo. Zanim bowiem game studies wyodrębniły się akademicko, grom cyfrowym przyglądali się reprezentanci innych dyscyplin (zauważmy, że np. socjologia nie została powołana do istnienia przez zawodowych socjologów). Takie badania mogą nam naświetlić dotychczasowe transfery kategorii analitycznych, nie odpowiedzą jednak, jak są one możliwe (tutaj wracamy do pewnej formy refleksji fundamentalnej, jednak o wiele skromniejszej niż np. u Husserla, gdyż zawężonej do konkretnego obszaru). Do rozwiązania postawionego problemu przybliża nas pojęcie definicji wstępnych pozwalające na krytyczne operowanie dostępnymi kategoriami, formułowanie za ich pomocą ostrożnych wniosków, a następnie ich empiryczne weryfikowanie i pogłębianie za pomocą ruchu dialektycznego między abstrakcją a konkretem. Każda analiza rzeczywistości wymaga bowiem wstępnego przyjęcia jakichś narzędzi pojęciowych, bez których myślenie nie może ruszyć z miejsca (poznanie nie przystępuje do swojego przedmiotu bezpośrednio, nie chwyta go od razu w całości na drodze nagłej iluminacji): ,samo gromadzenie faktów

35 M. Filiciak, Media, wersja beta. Film i telewizja w czasach gier komputerowych i internetu, Gdańsk 2013, s. 19-20. 
wymaga jakiejś uprzedniej teorii, tak że fakty i teoria są zawsze ze sobą dialektycznie związane" ${ }^{36}$. Całej tej pracy badawczej towarzyszyć musi świadomość faktu społecznej konstrukcji podmiotu, której istotnym narzędziem pozostaje język.

Na koniec chciałbym zaznaczyć, że poglądy przytaczanych powyżej autorów pozwoliłem sobie potraktować w sposób bardzo swobodny (nierzadko musiałem też rekonstruować je w sposób szkicowy, co zawsze rodzi ryzyko pewnych uproszczeń i deformacji). Bowiem ani Marks, ani też Durkheim nie byli badaczami gier wideo - w ich czasach medium to w ogóle jeszcze nie istniało. Nie stoi to jednak na przeszkodzie, aby w ich rozważaniach szukać metodologicznych inspiracji, które mogą zostać z pożytkiem wykorzystanie na niwie game studies. Również w rozdziale o społecznym konstruowaniu podmiotowości nie mogłem należycie wniknąć w złożone i skomplikowane zagadnienia, które zostały tam poruszone. Chodziło jedynie o wzbogacenie metodologicznej refleksji nad grami wideo o wątki nie-substancjalistycznej teorii podmiotowości.

\section{SUBJECTIVITY AND TRANSFER OF CONCEPTS IN VIDEO GAME RESEARCH}

\section{Summary}

The aim of the considerations presented in this article are to determine on what terms the concepts from different disciplines (theory of film, literature) can be used on the filed of game studies. At the beginning of the research on given medium we can't know to what extent it is possible to use the concepts pertain to another medias in a principled way. There is a risk that instead of investigating the chosen element of reality we'll - in a conscious or unconscious way - construct it with the available concepts (the lapse of speculation). In my considerations I try to show different methodological ways to solve this problem. Forming them I loosely refer to selected elements of Immanuel Kant's, Edmund Husserl's, Emile Durkheim's and Karl Marx's thought and to writings of visual media scholars. My investigation are based on non-subssantial theory of subjectivity.

Keywords: new media, methodology, video games, subjectivity

36 J. Lewis, Nauka, wiara i sceptycyzm, tłum. W. Krajewski, Warszawa 1961, s. 54. 